\title{
Penyelesaian Sengketa Tanah Akibat Bencana Alam di Kecamatan Bruno, Kabupaten Purworejo
}

\section{Iman Wahyu Aji*}

LBH Sakti, Purworejo, Indonesia

*email: imanajie4@gmail.com

DOI: https://doi.org/10.37729/amnesti.v2i2.655

Submitted: Juni 2020

Revised: Juli 2020

Accepted: Juli 2020

\section{ABSTRAK}

Kata kunci : $\quad$ Bencana alam berupa tanah longsor acapkali terjadi di wilayah

Sengketa,

sengketa tanah,

penyelesaian

sengketa
Kecamatan Bruno Kabupaten Purworejo menyebabkan timbulnya berbagai masalah, salah satunya adalah masalah hukum. Pergeseran tata letak tanah, runtuhnya bangunan serta akibat lain yang menimpa warga terdampak bencana. Kurangnya kesadaran akan pentingnya mempertahankan hak atas tanah serta rendahnya sosialisasi berkaitan dengan kepentingan hukum mendorong penulis untuk melakukan penelitian terhadap kejadian tersebut. Penulisan Hukum ini bertujuan untuk memberikan pengetahuan kepada masyarakat Kecamatan Bruno pada khususnya terkait dengan hak-hak serta kewajiban untuk mempertahankan hak milik atas tanah. Metode penyelesaian sengketa jika terdapat sengketa yang timbul akibat bencana alam berupa tanah longsor. Penelitian Hukum ini menggunakan jenis penelitian Deskriptif dimana menggunakan metode pendekatan yuridis sosiologis, dimana pendekatan dilakukan secara langsung kepada warga terdampak bencana tanah longsor. Jenis data yang digunakan berupa data primer dan sekunder. Penyelesaian sengketa yang timbul akibat bencana alam harus dilakukan secara cepat, tepat dan hemat. Guna mencegah adanya perselisihan dalam lingkungan desa. Hasil dari penelitian menyimpulkan bahwa penyelesaian sengketa yang terjadi lebih dominan dilakukan dengan jalur Non-Litigasi berupa 


\begin{tabular}{|c|c|}
\hline & $\begin{array}{l}\text { mediasi. Guna mempertemukan para pihak yang bersengketa dan } \\
\text { menghemat waktu serta anggaran. }\end{array}$ \\
\hline & ABSTRACT \\
\hline $\begin{array}{l}\text { Keywords: } \\
\text { Disputes, land } \\
\text { disputes, dispute } \\
\text { resolution }\end{array}$ & $\begin{array}{l}\text { Natural disasters in landslides often occur in the Bruno Subdistrict, } \\
\text { Purworejo Regency, causing various problems, one of which is legal } \\
\text { problems. Shifts in the layout of the land, the collapse of buildings and } \\
\text { other consequences for residents affected by the disaster. The lack of } \\
\text { awareness of the importance of defending land rights and the lack of } \\
\text { socialization related to legal interests prompted the author to research the } \\
\text { incident. This legal writing aims to provide knowledge to the people of } \\
\text { Bruno District, in particular, related to the rights and obligations to } \\
\text { maintain property rights on the land. Dispute resolution methods if } \\
\text { disputes are arising from natural disasters in the form of landslides. This } \\
\text { legal research uses a descriptive research method that uses a sociological } \\
\text { juridical approach, where the approach is carried out directly to residents } \\
\text { affected by landslides-types of data used in the form of primary and } \\
\text { secondary data. Settlement of disputes arising from natural disasters must } \\
\text { be carried out quickly, accurately, and economically to prevent disputes } \\
\text { within the village environment. The study results conclude that the } \\
\text { settlement of disputes that occur is more dominantly carried out by non- } \\
\text { litigation in the form of mediation. To bring together the disputing parties } \\
\text { and save time and budget. }\end{array}$ \\
\hline
\end{tabular}

\section{PENDAHULUAN}

Negara Republik Indonesia sebagai suatu negara hukum yang bersifat agraris, maka tanah merupakan salah satu memegang peranan penting dalam pembangunan. Tanah merupakan kebutuhan dasar umat manusia, karena manusia membutuhkannya sebagai tempat berpijak dan tempat untuk menjalani aktifitasnya. Aktifitas tersebut berfungsi untuk mensejahterakan hidup manusia yang dapat menunjang kehidupannya, seperti bercocok tanam, membangun rumah untuk tempat tinggal, dan kegiatan lainnya.

Menurut Kamus Besar Bahasa Indonesia, tanah merupakan permukaan bumi atau lapisan bumi yang berada di lapisan paling atas, keadaan bumi di suatu tempat, permukaan bumi yang diberi batas, bahan-bahan dari bumi, bumi sebagai sesuatu (pasir, cadas, napal, dan sebagainya) (Pulungan \& Muazzul, 2019). Atas dasar kebutuhan terhadap tanah yang semakin meningkat, maka negara memiliki hak untuk mengatur di bidang pertanahan, 
sehingga negara harus membuat peraturan yang dapat menunjang dan mengakomodir permasalahan permasalahan mengenai bidang pertanahan, sehingga rakyat mendapatkan perlakuan yang lebih adil mengenai permasalahan di bidang pertanahan.

Permasalahan pertanahan adalah suatu permasalahan yang cukup komplek dan membutuhkan waktu yang panjang dalam menyelesaikannya. Oleh karena itu, dapat dijelaskan bahwa permasalahan pertanahan merupakan suatu permasalahan yang cukup rumit dan sensitif sekali, karena menyangkut berbagai aspek kehidupan bersifat sosial, ekonomi, politis, psikologis dan lain sebagainya, akan tetapi juga harus memperhatikan berbagai aspek kehidupan, lainnya agar penyelesaian persoalan tersebut tidak berkembang menjadi suatu keresahan yang dapat mengganggu stabilitas masyarakat (Djaja, 2018).

Permasalahan di bidang pertanahan di Indonesia ini juga disebabkan oleh beberapa faktor, salah satu faktor penyebab itu adalah bencana alam, seperti bencana alam tsunami, bencana tanah longsor, bencana alam banjir, dan bencana alam lainnya. Salah satu bencana alam yang sering mengakibatkan kerugian dan kerusakan yaitu tanah longsor yang terjadi di Kecamatan Bruno. Tanah longsor yang terjadi di Kecamatan Bruno tersebut merupakan salah satu bencana alam yang cukup fenomenal karena telah mengakibatkan kerusakankerusakan yang cukup parah. Selain menimbulkan banyak korban jiwa, kerusakan infrastruktur, bahkan tatanan masyarakat pun menjadi terganggu. Apabila melihat dari status hukum dan fisik atas tanah, terdapat beberapa masalah pertanahan yang terjadi pasca bencana alam tanah longsor di Kecamatan Bruno, Kabupaten Purworejo, antara lain sebagai berikut :

1. Tanah masih ada, tetapi tidak memiliki tanda batas pada persil bidang tanah;

2. Tanah masih ada, tetapi administrasi dokumen pembuktian hak atas tanah hilang;

3. Tanah masih ada, tetapi pemilik hak atas tanah ikut hilang pada saat bencana alam tsunami terjadi;

4. Bukti kepemilikan hak atas tanah masih ada, tetapi bentuk tanah telah mengalami perubahan pada bentuk fisik atau tanah musnah akibat terjadinya bencana alam dan sama sekali tidak dapat dikuasai secara fisik dan/atau tidak depat dipergunakan lagi sesuai dengan fungsinya.

Permasalahan lain pun muncul seperti rusaknya sertifikat hak atas tanah yang disebabkan kerusakan yang tidak disengaja akibat bencana alam ataupun 
kerusakan karena kertas yang termakan usia maupun tersobeknya sertifikat karena kecerobohan pemegangnya, yang menyebabkan tidak bisa terpakainya sertifikat tersebut (Sudarmawan \& Surata, 2017). Selain rusaknya sertifikat, masalah lain yang dihadapi pemegang sertifikat adalah hilangnya sertifikat yang tidak diketahui keberadaannya, sehingga hal tersebut sangat merugikan pemilik hak atas tanah.

Bencana ini menimbulkan komplikasi permasalahan dalam hal penataan dan penemuan kembali identitas tanah hak milik, karena hancurnya batasbatas tanah, dan hilangnya bukti-bukti atas kepemilikan tanah akibat bencana gempa bumi. Surat-surat kepemilikan yang dimiliki oleh masyarakat turut hilang karena ikut terendam tanah pada saat bencana itu terjadi. Mereka yang selamat pun belum tentu mempunyai surat kepemilikan tanahnya. Selain itu, lembaga-lembaga terkait yang memiliki salinan dan arsip dokumen-dokumen hak kepemilikan tanah masyarakat juga ikut hancur dan hilang karena kantornya turut terkena bencana.

Permasalahan ini diperparah dengan besarnya jumlah tanah yang tidak tercatat dengan resmi dan hilangnya catatan tertulis yang disertai musnahnya tanda batas tanah membuat proses penentuan kepemilikan tanah adat ataupun tanah yang terdaftar, menjadi sulit. Banyaknya tanah yang tidak terdaftar akibat bencana alam ini, terdapat beberapa keadaan yang dapat menimbulkan permasalahan atas tanah tersebut. Penyelesaian hak milik atas tanah tersebut sebenarnya dapat diselesaikan antara lain dengan jaminan kepastian dan perlindungan hukum yang efektif oleh pemerintah dan lembaga-lembaga terkait terhadap hak kepemilikan atas tanah (Kuswanto \& Atmoko, 2019).

Keberadaan mengenai tanah dan hak-hak yang melekat di atas tanah di Indonesia, diatur dalam Undang-Undang Nomor 5 tahun 1960 Tentang Peraturan Dasar Pokok-pokok Agraria. Undang-Undang Pokok Agraria mengatur mengenai definisi tanah, yang dapat disimpulkan sebagai permukaan bumi yang dalam penggunaannya meliputi sebagian tubuh bumi yang ada di bawahnya dan sebagian dari ruang yang ada di atasnya dengan pembatasan sekedar diperlukan untuk kepentingan yang langsung berhubungan dengan penggunaan tanah yang bersangkutan dalam batas menurut Undang-Undang Pokok Agraria.

Menghadapi kasus-kasus konkret, diperlukan penataan tanah kembali yang memungkinkan bagi para pemegang hak atas tanah untuk dengan mudah membuktikan haknya atas tanah yang dikuasai, dan juga kebijakan dan 
pemerintah untuk memberikan kepastian hukum hak atas tanah pasca bencana alam gempa bumi di Kecamatan Bruno. Undang-Undang Dasar Republik Indonesia Amandemen ke IV Tahun 1945 telah memberikan landasan yakni dalam Pasal 33 ayat (3). Ketentuan pendaftaran tanah di Indonesia diatur dalam Pasal 19 Undang-Undang Pokok Agraria yang memerintahkan diselenggarakannya pendaftaran tanah dalam rangka menjamin kepastian hukum dan perlindungan hukum kepada pemegang hak atas tanah, dengan alat bukti yang dihasilkan pada akhir proses pendaftaran tersebut berupa buku tanah dan sertifikat tanah yang terdiri dari Salinan Buku Tanah dan Surat Ukur (Sutedi, 2007).

Ada 2 (dua) keadaan yang akan menimbulkan permasalahan dan penyelesaian terhadap hak milik atas tanah. Pertama, jaminan kepastian ataupun perlindungan yang efektif terhadap hak kepemilikan atas tanah. Kedua, prinsip pendaftaran tanah dan ataupun Peraturan PerundangUndangan lainnya secara langsung atau tidak langsung akan mempengaruhi pejabat atau pegawai pertanahan, melakukan perlindungan hak kepemilikan atas tanah, yang bersangkut paut dengan registrasi dan ajudikasi pemberian kepastian hukum kepada individu atas pemilik tanah korban bencana alam gempa bumi.

Indonesia sebagai negara yang berlandaskan hukum, dalam menanggulangi masalah pertanahan khususnya terhadap hak atas tanah sejak tahun 1960 Pemerintah menghapuskan sistem dualisme yang sudah ada sejak Pemerintah Hindia Belanda dengan mengeluarkan Undang-Undang Nomor 5 Tahun 1960 tentang Undang-Undang Pokok Agraria (UUPA). Dengan berlakunya Undang-Undang Pokok Agraria tersebut, maka terciptalah kesatuan hukum (unifikasi) di bidang hukum agraria di negara kita, sehingga segala tindakan hukum yang berkaitan dengan masalah tanah harus dilaksanakan berdasarkan Undang-Undang Nomor 5 tahun 1960 tersebut. Pendaftaran tanah menurut Pasal 19 ayat (1) Undang-Undang Pokok Agraria disebutkan :

"Untuk menjamin kepastian hukum oleh pemerintah diadakan pendaftaran tanah diseluruh wilayah Republik Indonesia menurut ketentuan-ketentuan yang diatur dengan Peraturan Pemerintah". 
Berdasarkan ketentuan pasal tersebut diatas, dapat diketahui bahwa untuk mewujudkan kepastian hukum dari kedudukan tanah, maka tanah harus didaftarkan dan harus mendapatkan alat bukti berupa sertifikat hak atas tanah.

Melalui kegiatan pengukuran akan terdapat adanya kepastian hukum mengenai letak, luas, batas-batas dari tanah yang merupakan data fisik yang kemudian diterangkan dalam surat ukur dan peta pendaftaran tanah. Kegiatan pendaftaran hak atas tanah akan tercapai kepastian hukum mengenai status hukum dari tanah yang bersangkutan terhadap subjek kepemilikannya yang merupakan data yuridis. Sebagai tindak lanjut dari ketentuan Pasal 19 ayat (1) Undang-Undang Pokok Agraria dikeluarkan Peraturan Pemerintah Nomor 24 Tahun 1997 tentang perubahan Peraturan Pemerintah Nomor 10 Tahun 1961 tentang Pendaftaran Tanah. Peraturan ini diharapkan terjaminlah kepastian hukum hak-hak atas tanah yang ada di wilayah Negara Kesatuan Republik Indonesia.

\section{METODE}

Penelitian ini menggunakan metode pendekatan yuridis sosiologis, yaitu suatu penelitian yang didasarkan pada suatu ketentuan hukum atau peraturan yang berlaku dengan fenomena atau kenyataan yang terjadi dilapangan serta dalam prakteknya sesuai dengan yang terjadi sebenarnya (Ishaq, 2017). Jenis penilitian yang digunakan penulis untuk memperoleh data adalah jenis penelitian deskriptif, yaitu suatu penelitian yang dimaksudkan untuk memberikan gambaran tentang keadaan subyek dan/atau objek penelitian sebagaimana adanya. Jenis penelitian deskriptif ini bertujuan untuk memberikan data seteliti mungkin secara sistematis dan menyeluruh mengenai konflik atas kepemilikan tanah yang timbul akibat bencana alam. Data Primair merupakan hasil dari wawancara pada beberapa warga di wilayah Kecamatan Bruno, Kabupaten Purworejo dan Badan Pertanahan Nasional Kabupaten Purworejo dengan cara melakukan interview kepada warga terdampak bencana. Data sekunder adalah sumber data penelitian yang diperoleh melalui media perantara atau secara tidak langsung yang berupa buku, catatan, bukti yang telah ada, atau arsip baik yang dipublikasikan maupun yang tidak dipublikasikan secara umum.

Teknik pengumpulan data yang dilakukan dengan cara observasi dan interview. Observasi yang dilakukan di Desa Brunosari, Kecamatan Bruno, 
Kabupaten Purworejo. Untuk pengumpulan data dengan mengadakan pengamatan secara langsung terhadap objek yang berkaitan dengan masalah yang diteliti. Dengan tujuan untuk mendapatkan data yang menyeluruh dari perilaku manusia atau sekelompok manusia sebagaimana terjadi dalam kenyataanya dan mendapatkan deskripsi yang relatif lengkap mengenai kehidupan sosial dan salah satu aspek. Wawancara yang dilakukan terhadap warga Desa Brunosari yang terdampak bencana tanah longsor untuk memperoleh informasi terkait aspek pokok penyeselsaian sengketa yang terjadi akibat bencana. Wawancara ini dilakukan dengan tujuan untuk memperoleh data atau keterangan-keterangan terhadap orang-orang yang dianggap mengetahui. Dimungkinkan diperoleh data yang berguna serta dapat dipertanggung jawabkan kebenaranya. Dalam penelitian ini dilakukan wawancara dengan warga Desa Brunosari, Kabupaten Purworejo, staf Kantor Pertanahan Kabupaten Purworejo.

Metode analisis data yang sesuai dengan penelitian deskriptif. Menjelaskan, menguraikan, dan menggambarkan rumusan data-data keterangan yang didapat dalam penelitian lapangan maupun penelitian kepustakaan, kemudian untuk selanjutnya di tarik kesimpulan. Teknik analisis data deskriptif merupakan teknik analisis yang dipakai untuk menganalisis data dengan mendeskripsikan atau menggambarkan data-data yang sudah dikumpulkan seadanya tanpa ada maksud membuat generalisasi dari hasil penelitian (Yuliani, 2019).

\section{HASIL DAN PEMBAHASAN}

Brunosari merupakan salah satu desa di Kecamatan Bruno dimana lokasi Desa Brunosari berada pada pusat Kecamatan Bruno. Luas total wilayah Desa Brunosari seluar 719,523 ha. Jumlah ini terbagi atas lahan permukiman seluas 101,723 ha, lahan persawahan seluas 130,600 ha, lahan perkebunan seluas 475,650 ha, dan lahan prasarana umum seluas 11,550 ha. Jumlah warga di Desa Brunosari sebanyak 4.509 jiwa dengan jumlah Kepala Keluarga sebanyak 1.082. Terdiri dari 2.226 owang laki-laki dan 2.283 orang perempuan. Dengan jumlah warga demikian, dibanding dengan luas wilayah Desa Brunosari dapat dikatakan bahwa kepadatan penduduk pada Desa Brunosari masih sangat minim (Perangkat Desa Brunosari, 2020). 
Bencana alam berupa tanah longsor yang paling sering terjadi di wilayah Kecamatan Bruno. Akibatnya timbul berbagai sengketa yang berkaitan dengan pertanahan, adanya tanah longsong tentu saja terdapat pergerakan tanah yang dapat merubah struktur tanah bahkan bangunan sekalipun. Hal ini tentu saja dapat menimbulkan masalah baru karena pada dasarnya setiap tanah yang ada di wilayah tersebut tentu saja dibatasi oleh sertifikat dengan bukti kepemilikan yang jelas (Mukmin, 2017). Jika terdapat pergeseran tanah sedikit atau banyak tentu akan berakibat hukum bagi para pemilik tanah yang terdampak bencana. Jika tidak ditindaklanjuti tentu akan timbul sengketa jika setiap terjadi bencana, oleh sebab itu baik dari warga dan perangkat desa harus sadar akan hukum terutama mengenai dampak dari bencana yang mau tidak mau akan menimbulkan konflik pada pemilik tanah.

Desa Brunosari pernah dilanda bencana tanah longsor pada tahun 2015 dan tahun 2017. Dusun Crogol pernah terjadi tanah bergerak yang berakibat rusaknya rumah warga. Hal ini terus terjadi apabila musim penghujan tiba, dan berhenti jika sudah memasuki musim kemarau. Gerakan tanah tersebut mengakibatkan beberapa kerugian terhadap warga, mulai dari tembok rumah yang retak hingga bergesernya struktur bangunan. Tahun 2017 terdapat bukit seluar $74 \mathrm{~m} 2$ yang bergeser di dekat pemukiman warga, dengan jarak kurang lebih hanya $14 \mathrm{~m}$ dari pemukiman, dimana terdapat setidaknya 15 rumah di sekitar bukit tersebut. Saat musim kemarau datang, retakan tanah tersebut sudah di antisipasi dengan cara membuat cor blok, namun karena sifat tanah yang labil sehingga setiap tahunnya terjadi retakan tanah yang sama.

Akibat dari dampak bencana tersebut maka perlu dilakukan penataan kembali baik secara administratif maupun secara yuridis terhadap berbagai persoalan yang berkaitan dengan masalah pertanahan diwilayah yang terkena dampak tanah longsor. Terutama yang berkaitan dengan dokumen hukum kepemilikannya, yaitu melalui pendataan ulang atas kepemilikan persil tanah melalui sertifikasi (pensertifikatan) terhadap tanah secara menyeluruh diwilayah bencana untuk menghindari terjadinya konfik pertanahan dikemudian hari.

Penyelesaian nonlitigasi merupakan mekanisme penyelesaian sengketa yang dilandasi oleh prinsip pemecahan masalah dengan bekerja sama yang disertai dengan itikad baik oleh kedua belah pihak untuk menemukan win-win solution (Alting, 2011). Proses pemecahan masalah dilakukan secara tertutup untuk umum dan kerahasiaan para pihak terjamin serta proses beracaranya 
lebih cepat dan efesien. Penyelesaian litigasi cenderung menghasilkan masalah baru karena sifatnya adalah win lose, tidak responsif, waktu beracaranya relatif lambat dan sering dilakukan dengan terbuka untuk umum (Winarta, 2012).

Mediasi di luar pengadilan di Indonesia dipayungi oleh UndangUndang Nomor 30 Tahun 1999 Tentang Arbitrase dan Alternatif Penyelesaian Sengketa. Langkah-langkah mediasi yang dilakukan pada para pihak yang bersengketa di Desa Brunosari sebagai berikut :

1. Para Pihak setuju untuk melakukan mediasi, karena mediasi sifatnya adalah sukarela.

2. Seleksi terhadap mediator,yang dilakukan oleh para piihak yang bersengketa.

3. Pertemuan Mediator dengan para pihak yang bersengketa, pertemuan dilakukan oleh mediator secara terpisah antara pihak yang satu dengan yang lainnya. Dalam hal ini yang bertindak sebagai mediator adalah Kepala Desa Setempat.

4. Fase-fase mediasi yang dilakukan sebagai berikut :

a. Melakukan identifikasi dan penjelasan terhadap persoalan dan permasalahan. Identifikasi masalah dilakukan dengan cara mendengarkan pendapat dari masing-masing pihak yang bersengketa.

b. Mengadakan ringkasan terhadap permasalahan dan membuat agenda untuk didiskusikan. Dalam hal ini Kepala Desa yang berwenang untuk membuat ringkasan masalah sengketa yang terjadi serta memberikan masukan-masukan kepada para pihak yang bersengketa.

c. Mendiskusikan setiap permasalahan satu demi satu. Masing-masing pihak berhak untuk memberikan bantahan dan jawaban dari hasil penyampaian materi dari Kepala Desa yang diberikan untuk mengklarifikasi sementara masalah yang ada.

d. Diskusi dalam pemecahan masalah. Kepala Desa dalam hal ini memberikan beberapa opsi yang dapat dipilih sebagai jalan untuk memecahkan masalah. Masing-masing pihak dapat memberikan pencapatnya demi mendapatkan hasil yang tidak merugikan satu sama lain.

e. Membuat satu persetujuan atau kesepakatan yang tertulis. Setelah adanya proses penyampaian pendapat antara masing-masing pihak hingga terdapat jalan keluar yang dipilih oleh masing-masing pihak. 
Selanjutnya Kepala Desa yang dibantu oleh Sekertaris Desa membuatkan surat kesepakatan yang dijadikan pedoman bagi masingmasing pihak yang bersengketa guna mengatur hak dan kewajiban masing-masing pihak.

Kesepakatan Mediasi diartikan sebagai kesepakatan yang dicapai oleh para pihak dengan bantuan mediator guna meyelesaikan atau mengakhiri sengketa. Pasal 39 Undang-Undang No 14 tahun 2008 tentang Kebebasan Informasi Publik menyebutkan: "Putusan Komisi Informasi yang berasal dari kesepakatan melalui mediasi bersifat final dan mengikat". Ketentuan ini tidak secara tegas menyebutkan bahwa Putusan Komisi Informasi memiliki titel eksekutorial, sehingga pemahaman para ahli hukum tentang ketentuan Pasal 39 ini dapat berbeda-beda.

\section{KESIMPULAN}

Penyelesaian sengketa yang terjadi akibat bencana tanah longsor dapat diselesaikan dengan 2 jalan yaitu secara Litigasi (persidangan) atau NonLitigasi (diluar persidangan). Pada praktiknya masyarakat Desa Brunosari yang terdampak bencana tanah longsor lebih memilih menyelesaikan sengketa yang terjadi dengan cara Non-Litigasi. Hal ini bertujuan untuk menghemat waktu serta biaya yang ditimbulkan apabila proses penyelesaian sengketa dilakukan dengan cara Litigasi (persidangan), yaitu mediasi. Mediasi merupakan cara penyelesaian sengketa melalui proses perundingan untuk memperoleh kesepakatan Para Pihak. Hasil kesepakatan mediasi yang di perentarai oleh Kepala Desa sudah diakui secara hukum dan dapat dilakukan pendaftaran ulang guna dilakukan pengukuran ulang tanah. Asalkan dalam objek sengketa tersebut telah berbentuk sertifikat bukan Leter $C$ atau persil desa.

\section{DAFTAR PUSTAKA}

Alting, H. (2011). Konflik Penguasaan Tanah Di Maluku Utara: Rakyat Versus Penguasa Dan Pengusaha. Jurnal Konstitusi, II(2), 266-282.

Djaja, B. (2018). Quo Vadis Undang-Undang Pokok Agraria? Suatu Tinjauan Terhadap Permasalahan Pertanahan di Usia Undang-undang Pokok Agraria yang ke Lima Puluh Delapan Tahun. Era Hukum - Jurnal Ilmiah Ilmu Hukum, 16(1). https://doi.org/10.24912/erahukum.v16i1.2372

Ishaq. (2017). Metode Penelitian Hukum Dan Penulisan Skripsi, Tesis, Serta Disertasi. In ALFABETA, cv. 
Kuswanto, H., \& Atmoko, A. D. (2019). Perlindungan Hukum terhadap Hak Atas Tanah Bersertifikat. TSL: The Spirit of Law, 6(1), 68-85.

Mukmin, A. (2017). Manfaat Sertifikat Tanah Sebagai Upaya Penertiban Administrasi Di Bidang Pertanahan. Yuriska: Jurnal Ilmiah Hukum, 3(1), 154. https://doi.org/10.24903/yrs.v3i1.192

Perangkat Desa Brunosari. (2020). Hasil wawancara dengan perangkat Desa Brunosari.

Pulungan, M. T., \& Muazzul. (2019). Tinjauan Hukum tentang Peralihan Hak Atas Tanah melalui Perjanjian Gadai di Bawah Tangan. Jurnal Ilmiah Penegakan Hukum, 4(2), 60. https://doi.org/10.31289/jiph.v4i2.1959

Sudarmawan, G. A., \& Surata, I. G. (2017). Kekuatan Hukum Sertipikat Pengganti Karena Hilang di Kantor Pertanahan Kabupaten Buleleng. Kentha Widya Jurnal Hukum, 5(2), 111-125.

Sutedi, A. (2007). Peralihan Hak Atas Tanah dan Pendaftarannya. Sinar Grafika.

Winarta, F. H. (2012). Hukum Penyelesaian Sengketa Arbitrase Nasional Indonesia dan Internasional. Sinar Grafika.

Yuliani, W. (2019). Metode Penelitian Deskriptif Kualitatif Dalam Perspektif Bimbingan dan Konseling. Quanta, 3(1), 9-19. https://doi.org/10.22460/q.v1i1p1-10.497 